\title{
Anticompetitive Effects of the Banking Cartel in Turkish Loan Market
}

Aydın ÇELEN (https://orcid.org/0000-0001-6415-0129), Department of Economics, Istanbul Ticaret University, Turkey;e-mail: acelen@ticaret.edu.tr

\section{Banka Kartelinin Türkiye Kredi Pazarındaki Rekabeti Sınırlayıcı Etkileri}

\begin{abstract}
The aim of this paper is to measure the effect of the banking cartel on the competition in the Turkish loan market. In doing this, we use Bresnahan-Lau model with alternative supply relation definitions. Our results suggest that Turkish banks operate in the perfectly competitive conditions during the non-cartel period. However, with the enforcement of the cartel actively between September 2007 and September 2011, the competition intensity in the market was damaged significantly. All alternative models witness the robust conclusion that the banking cartel affected the competition in the loan market adversely.

Keywords : Cartel, Competition, Turkish Banking, Bresnahan-Lau Model.

JEL Classification Codes : G21, L13, L40, D43.

$\ddot{\mathbf{O} z}$

$\mathrm{Bu}$ çalışmanın amacı, banka kartelinin Türkiye kredi pazarındaki rekabete olan etkisini ölçmektir. Buna yönelik olarak, alternatif arz ilişkisi tanımlarını temel alarak Bresnahan-Lau modelini kullandık. Sonuçlar, Turkiye'de bankaların kartel içerisinde olmadıkları dönemlerde tam rekabet koşullarında faaliyetlerini sürdürdüklerini göstermektedir. Ancak, kartelin aktif olarak yürütüldüğü Eylül 2007 ve Eylül 2011 ayları arasındaki dönemde, kredi pazarındaki rekabet önemli seviyede zarar görmüştür. Tüm alternatif model tanımlamaları, banka kartelinin kredi pazarındaki rekabeti olumsuz yönde etkilediğine işaret etmektedir.
\end{abstract}




\section{Introduction}

Turkish Competition Act has been enforced effectively by the Competition Board since the Board was first formed in 1997. Throughout twenty years, the Board has supervised the banking market closely and carried out three separate in-depth investigations on this market.

Although Turkish competition rules are enforceable in all sectors, without any exceptions, several warnings have been raised by representatives of the sector throughout banking investigations. They frequently stressed that they were the backbone of the Turkish economy, thus the Competition Board should consider the sui generis of this sector and avoid increasing its vulnerability (Reuters, 2013) ${ }^{1}$. Despite all these warnings, the Board did not abstain from imposing a considerable number of administrative fines on the banks breaching the Competition $\mathrm{Act}^{2}$.

Among three investigations on banking sector, the second one whose final decision was published in March 2013 has the utmost importance for several reasons. First, after lengthy and detailed investigation, the Board achieved to prove that the banks infringed the Competition Act in the period 2007-2011 by harmonizing interest rates for deposit, loan and credit card services. Second, the investigation was carried out on 12 major banks whose total market share was more than eighty per cent. Third, the Board broke its records in this decision by imposing enormous amount of the fines on banks: Total fine was TRY 1.1 billion (approximately EUR 480 million) and it is the highest fine in the Board's history, more than four times larger than the previous record fine. In addition, the record of the highest fine ever imposed on a single firm is also broken in this decision: A fine of TRY 213 million (approximately EUR 92 million), more than double of the previous record.

In this study, we aim to estimate the anticompetitive effects, if any, of the infringements found by the Competition Board in the above-mentioned unprecedented decision. For this aim, we especially focus on the consumer loan submarket, and measure the likely impact of the cartel on the intensity of the competition in this submarket. In doing

1 The relationship between competition and stability in banking sector and the applicability / suitability of classic antitrust tools to this sector are other interesting topics to study. For a comprehensive review on these topics, see Carletti and Hartmann (2002) and Beck (2008).

2 Sahin (2017) claims that these warnings affected the Board, at least partially: The Board can fine firms infringing the Competition Law up to 10 per cent of their turnover generated in the previous year. Furthermore, in the Monetary Fines Regulation 2009 the Competition Board determines the "base fine" for cartels as between 2-4 per cent of cartel members' turnover. The Board did not apply this rule intentionally in any of the abovementioned decisions on banks and imposed significantly lower per cent fines on them although all infringements detected were cartels without any doubt. Despite all, these decisions showed that the Turkish banking sector is under the close scrutiny of the Board. 
this, we used a model suggested by Bresnahan (1982) and Lau (1982), which is the root of the "New Empirical Industrial Organisation" (NEIO).

The results of our study are important to justify the heavy fines imposed by the Board. Because in the above-mentioned decision, the Board stated that the agreement among the banks harmed competition by its very nature although it did not prove clearly its negative effects on competition.

The paper is organized as follows: The next section gives information regarding the competition law and banking sector in Turkey. Section 3 provides the theoretical background of the Bresnahan-Lau methodology. In Section 4 we review the relevant literature. The description of the empirical model and data used in this study is presented in Section 5. Section 6 is devoted to the empirical results of the model. And finally, Section 7 discusses the findings, and concludes.

\section{Competition Law and the Banking Sector in Turkey}

In Turkey, Turkish Competition Act, numbered 4054, was adopted in 1994. The aim of the Act is to prevent agreements, decisions and practices which restrain, distort or restrict competition in markets for goods and services, as well as abuse of dominant position by dominant firms in the market.

It would be possible to mention two main legal bases for the Competition Act. The first one is the Article 167 of the Turkish Constitution entrusting the state with the burden of taking the measures that provide the appropriate and ordered functioning of markets for money, credit, capital, goods and services, and to impede monopolization and cartelization which are observed de facto or as a result of agreement. The other one is EEC-Turkey Association Agreement (Ankara Agreement) dated back to 1963, necessitating harmonization of Turkish legislation to that of European Union. Thus, the provisions of the Turkish Competition Act are parallel to those of Treaty of Rome, namely Articles 81 and 82.

Although adopted in 1994, the Turkish Competition Act started to be applied in 1997 with the formation of the authority responsible for enforcing it. Competition Authority has carried out three separate investigations on banking sector during its history. In the first two the Turkish banks were investigated while the parties subjected to third investigation were the global banks.

In March 2011, the Competition Board completed its investigation on eight banks functioning in Turkey. It decided that seven banks (Akbank, Denizbank, Finansbank, Garanti Bankası, Halkbank, İş Bankası, Vakıfbank, Yapı ve Kredi Bankası) infringed Article 4 of the Competition Act by making a cartel agreement on their promotional offers to firms to obtain salary/wage payments. In this decision, the Board alleged the banks to be part of a “gentleman's agreement" implemented since 2001. The following infringements are found in this agreement: (1) Prevention of the promotions for direct deposit of salaries/wages of 
private companies, (2) Prevention of the proposals to the undertakings which have promotion agreement with other banks.

In this decision, the Board levied turnover-based monetary fines against investigated banks, at different per cent of their turnovers. It imposed a 0.4 per cent fine on five banks and a 0.3 per cent fine on the other two, amounting a total fine TL 72.3 million (approximately EUR 30 million). Although at the time this fine was the highest fine that was ever imposed by the Board in its 14-year history, the amount of the fine was found to be too low (Gonlusen, 2013). Meanwhile, the highest fine imposed on a single bank (on Akbank) in this investigation was TL 14.5 million (approximately EUR 6.0 million).

In March 2013, Competition Board took another important decision related with the banking sector, which is the topic of our study. It carried out an in-depth investigation into the 12 Turkish banks (Akbank, Denizbank, Finansbank, HSBC, ING, TEB, Garanti, Halkbank, İş Bankası, Vakıfbank, Yapı Kredi Bankası and Ziraat Bankası). At the end, the Board concluded that these banks infringed competition laws through a collusion to harmonize their trade terms for cash deposit interest, credit interest and credit card fees. To be more specific, the banks colluded in the period 2007-2011 about harmonization of interest rates, fees and commissions for cash deposit services, loan services and credit card services.

The Board imposed fines against all 12 of the investigated banks. The rates varied between $1.5 \%$ and $0.3 \%$ of the defendants' 2011 turnovers. As stated above, the total fine amounted to TRY1.1 billion (approximately EUR 480 million), which is the highest fine, four times larger than the previous record. It is also the highest fine ever imposed on a single undertaking - a fine of TRY 213 million (approximately EUR 92 million) was levied on Garanti Bankasi, two times larger than the previous record fine of TRY 92 million, which was imposed in 2011 against Turkcell.

The Competition Board launched another investigation on 13 global banks upon the leniency application ${ }^{3}$ of the Bank of Tokyo Mitsubishi UFJ, which admitted that the banks have breached competition law. The banks have been accused of distributing the loans with higher interest rates to their Turkish clients like Turkcell and Tüpraş. The competition investigation committee reached to the conclusion that seven out of 13 investigated banks should be fined up to 4 percent of their turnover. However, the Board imposed fines on only two of them in November 2017: ING Bank was fined TRY 21 million (EUR 4.5 million) and RBS Istanbul branch was fined TRY 66,000 (EUR 14,072). Although Bank of Tokyo Mitsubishi UFJ was also found to violate the competition rules, it was not fined due to its leniency application.

3 Competition authorities have started to adopt leniency programs to give incentives (i.e. no fine or reduction in fines) to cartel members to confess their participation in a cartel and cooperate with the competition law enforcers to escape from the heavy sanctions of the competition laws (UNCTAD, 2016). 
In these decisions, the Board seems to embrace the traditional view (Várhegyi, 2004) that fiercer competition among banks is better for the society in general because it ensures the minimization of costs and guarantees an efficient allocation of funds. Meanwhile, all of the banks-imposed fines in these decisions appealed them before the administrative courts, but they failed to reserve them.

\section{Theoretical Framework}

In determining the effects of the banking cartel on the degree of competition in the loan sector, we utilized the popular Bresnahan-Lau model. This model can be used in order to measure the degree of competition in general, or market power of a firm in particular.

Bresnahan-Lau model is a member of the so-called conjectural-variation methodology. With the term of the conjectural variation, we imply the beliefs of a firm about its rivals' reactions if it changes its output or price (Bowley, 1924). This methodology has been introduced in order to the overcome a problem of the well-known Lerner index ${ }^{4}$ : High profit margins in a market can be observed for two reasons: It may be due to inelastic demand or collusive behaviors of the players. The Lerner index cannot distinguish between these two reasons. The conjectural-variation methodology aims to isolate the changes in the Lerner index due to demand changes from the changes stemming from firms' behaviours, and therefore separate firms' competitive behavior (Leon, 2014).

Bresnahan-Lau model relies on two important assumptions. First, it assumes that players in the market aim to maximize their profits (Mensi, 2010). Second, the players are assumed to be input-price-takers in the upper segment of the market (Toolsema, 2002). In the Bresnahan-Lau model, the market price and quantity are determined by the intersection of the two functions; demand and supply functions. The demand equation may be written follows:

$$
Q=D(P, Z ; a)+\varepsilon
$$

where $Q$ is quantity, $P$ is price, $Z$ is a vector of exogenous variables affecting demand, e.g. the price of a substitute or income, $a$ is a vector containing the parameters of the demand system to be estimated, and $\varepsilon$ is the econometric error term ${ }^{5}$.

The supply function is produced from the firm's profit maximizing problem, and it varies according to the competition intensity in the market. At the polar case of the perfect

4 The Lerner index (or price-cost margin) is a popular measure of market power in empirical research. The market power of a firm is identified by the divergence between the firm's price and its marginal cost. The price and marginal cost should be equal in perfect competition but will diverge in less competitive environments. A bigger margin (mark-up) between price and marginal cost indicates greater market power (Leon, 2014). For example, $Q=\alpha_{0}+\alpha_{P} P+\alpha_{Z} Z+\varepsilon$ is a linear demand equation with one exogenous variable. 
competition, the sellers cannot affect the prices, and accept the prices as given, resulting in the equality between price and marginal cost. This equality may be shown as follows:

$$
P=M C(Q, W ; b)+\rho
$$

where $M C(\cdot)$ denotes the marginal cost, $W$ is a vector of exogenous variables on the supplyside, e.g. input prices, $b$ the supply-function parameters to be estimated, and $\rho$ the supply error.

On the other hand, when the market is not perfectly competitive, perceived marginal revenue, not price, is equal to marginal cost. This can be expressed as follows:

$$
P=M C(Q, W ; b)-\lambda \cdot h(Q, Z ; a)+\rho
$$

where $P+h(\cdot)$ is marginal revenue, $P+\lambda h(\cdot)$ is marginal revenue as perceived by the firm. Since the demand-side parameters and exogenous variables, namely $(Q, Z$ and $a)$ affect marginal revenue they are included into $h(\cdot)^{6}$, which is called semi-elasticity of market demand. In this specification, $\lambda$ is a measure of market power and called conduct parameter. This parameter is a measure of markup between price and marginal cost. At the one extreme point, when $\lambda=0$ the market is perfectly competitive, and thus marginal cost equals price. On the other extreme, the case of $\lambda=1$, a perfect cartel or monopoly case is valid and market power reaches its maximum level, and intermediate $\lambda$ values between 0 and 1 imply some market power in oligopoly situations.

One cannot identify the value of $\lambda$ by just solving equations 1 and 2 ' simultaneously: We cannot distinguish competition and cartel cases in this system if the demand function does not satisfy some necessities explained below. Following Bresnahan's (1982) study, it is possible to show the identification problem of market power parameter, $\lambda$ by using the simplest linear versions of both demand and supply equations:

The demand equation is

$$
Q=a_{0}+a_{P} P+a_{Z} Z+\varepsilon
$$

and the marginal cost function is $M C=b_{0}+b_{Q} Q+b_{W} W$. Then, according to the condition $P=M C(\cdot)-\lambda \cdot h(\cdot)+\rho$, the supply relation takes the form as follows:

$$
P=b_{0}+b_{Q} Q+b_{W} W-\lambda\left(Q / a_{P}\right)+\rho
$$

In such a model, we can identify the demand equation for all forms of the supply relation. The demand equation (3) has only one included endogenous variable, $P$, and there

6 When the profit maximisation problem is solved, the exact value of $\mathrm{h}(\cdot)$ is found as $Q\left(\frac{\partial D^{-1}(Q)}{\partial Q}\right)$. 
is an excluded exogenous variable, $W$, so the equation is identified. In a similar way, supply relation (4) is also identified. For the supply relation, there exists one included endogenous variable, $Q$, and one excluded exogenous variable, $Z$.

However, the market power parameter, $\lambda$, cannot be determined in such a system. In order to see this problem, supply relation (4) can be rewritten as follows:

$$
P=b_{0}+\gamma Q+b_{W} W+\rho
$$

where $\gamma=b_{Q}-\lambda / a_{P}$. In this system, it is possible to estimate the parameter of variable $Q$, namely $\gamma$, which is dependent on $b_{Q}, \lambda$ and $a_{P}$. Although $\alpha_{P}$ is known due to demand function, the other two parameters, $b_{Q}$ and $\lambda$, cannot be determined separately. In other words, we cannot know whether we are moving on $P=M C$ or $M R=M C$, and the market power parameter can take any value between 0 and 1 .

Bresnahan (1982) solved the problem of identifying $\lambda$ by adding an exogenous variable to demand function which not only shifts its intercept up and down but also rotates it. In other words, if we can find an exogenous variable to change the slope of the demand function, we can identify the market power parameter, $\lambda$.

In Bresnahan's (1982) model, the variable rotating demand curve and thus helping in identifying the market power parameter is an interaction term between variables $P$ and $Z$. So, the demand equation (3) in the simple example has been altered to

$$
Q=a_{0}+a_{P} P+a_{Z} Z+a_{P Z} P Z+\varepsilon
$$

where $P Z$ is the interaction variable between variables $P$ and $Z$. Accordingly, the supply relation turns out to be the following structure:

$$
P=b_{0}+b_{Q} Q+b_{W} W-\lambda\left(Q / a_{P}+a_{P Z} Z\right)+
$$

The demand equation $\left(3^{\prime}\right)$ is still identified because only one exogenous variable $(P Z)$ is included into the demand equation ${ }^{7}$. Therefore, the parameters $\alpha_{P}$ and $\alpha_{P Z}$ can be considered as known while dealing with the supply relation. In the supply relation (4'), we have two included endogenous variables, $Q$ and $Q^{*}$, where $Q^{*}=Q / a_{P}+a_{P Z} Z$; and two excluded exogenous variables, $Z$ and $P Z$. Consequently, the supply relation is also identified, and the market power (conduct) parameter, $\lambda$, can be identified as the coefficient of $Q^{*}$.

The movements of exogenous variables can rotate the demand curve, and its conditions were established by a companion paper of Lau (1982). According to the so-called

7 For the demand equation (3'), there exist one included endogenous variable, P, and one excluded exogenous variable, $\mathrm{W}$. 
impossibility theorem by Lau (1982), almost any functional form for the demand curve leads to identification except two most commonly used forms: linear and log-linear. Henceforth, in order to measure the market power parameter, one must add an interaction term (like suggested by Bresnahan (1982)), a squared term or another variable that introduces nonlinearity and permits the demand curve to rotate. In the literature, several variables have been used as the rotation variable: Suominen (1994), Shaffer (1993) and Toolsema (2002) contain income in addition to the interaction term between price and substitute price. In Buschena and Perloff (1991), two-time trends are used as rotation variables. In their study of advertising market, Jung and Seldon (1995) choose the number of new products introduced to represent Z. Demirel and Hatırlı (2017) used income, unemployment rate and weighted bill-bond interest rate as the rotation variables.

\section{Literature Review}

In literature, we encounter plenty of studies applying the Bresnahan-Lau model on banking sectors with different motivations. This is probably due to the fact that this model needs only aggregated sectoral data, which is mostly easy to have in banking. A few examples of the studies in this stream are as follows: Shaffer (1989) and Shaffer (1993) use the method and show that in both US and Canada the banks are more competitive than Cournot competition. Suominen (1994) uses the model in order to assess the effect of the deregulation on the competition in the Finnish baking industry. He reaches an unexpected result that market power of the banks increased with the deregulation. With a similar motivation, Zardkoohi and Fraser (1998) utilize the model to measure the effect of the geographical deregulation in US banking sector. They find only a small competitionincreasing effect of the regulation. Qin and Shaffer (2014) use the model to measure the competition intensity among the Chinese bank during the period between 1986 and 2011. Their results strongly reject monopoly power and indicate perfectly competitive behavior. In addition, they show that China's entry into the World Trade Organization (WTO) did not create any significant effect in banking competition. Swank (1995) applies a dynamic version of the model on the Dutch markets for mortgages and deposits over the period 1957 1990. The results of this study indicate that both markets are less competitive than Cournot competition, but the competition in the mortgages market intensified in the course of the 1980s.

The number of the studies applying the Bresnahan-Lau model on Turkish banking industry is limited. We have only five papers examining competition conditions in this sector. Four out of five focus on only deposit sub-sector of the banking sector. There exists just one study examining the competition in the Turkish loan market in the framework of the Bresnahan-Lau model, to our best knowledge.

Korkmaz (2010) studies the Turkish deposit banking for the period between 1990 and 2008 in order to assess whether the competition level increased in the year 2001. His findings show that the deposit market operated in perfectly competition conditions before and after 2001, which is not in line with the results of the successive studies, namely TBB (2012), Aydemir (2014) and Demirel and Hatırlı (2017). 
TBB (2012) studies the competitive conduct of the Turkish banks in the deposits market for four different periods (1970-2009, 1980-2009, 1990-2009, and 2000-2009) through the Bresnahan-Lau model. The results witness that monopolistic competition conditions were observed in the deposit market for a long time, and the competition in the market increased in the recent years (after 2000). However, under no circumstances are the market conditions called as perfectly competitive in any time period studied.

Aydemir (2014) estimates the intensity of the competition in Turkish deposits market during the period 2002-2011. It is demonstrated that the Turkish banks have determined deposit interest rates collusively during this period. He also investigates the effect of the banks' sizes on collusive behavior and shows that smaller banks have colluded more extensively in comparison to the larger banks. This study also shows that collusive behavior among Turkish banks has decreased following the 2008 global financial crisis.

Demirel and Hatırlı (2017) examine the degree of competition in the Turkish deposit market between 2000-2013 using Bresnahan-Lau model. Their estimations suggest that the Turkish deposit market operates under monopolistic competition conditions.

Competition condition in the Turkish loan market is studied only by Aydemir (2013) in the conjectural variation framework. His results demonstrate that Turkish banks adopted the collusive behavior in the loan market throughout the period 1988-2009. He claims that the Competition Board imposed fines on Turkish banks rightfully and it is crucial to scrutinize the market more closely by Competition Board and the Banking Regulation and Supervision Agency.

\section{Empirical Model and Data}

In this study, to estimate the likely impact of the banking cartel on the competition in the Turkish consumer loan market, two variables, consumer confidence index $(C)$ and average cost of domestic borrowing $(B)$, have been used to make MR curve rotate. We expect that these variables have negative effects on the consumer loans offered by banks $(Q)$. Hence, the demand function is given by

$$
Q=a_{0}+a_{P} P+a_{C} C+a_{P C} P C+a_{B} B+a_{P B} P B+\varepsilon
$$

In the second equation, namely in the supply relation, we selected two obvious cost items as explanatory variables. They are weighted average interest rates applied to bank deposits $(R)$ and personnel expenses $(E)$. Accordingly, the supply relation is specified as

$$
P=b_{0}+b_{Q} Q+b_{R} R+b_{E} E+\lambda Q^{*}+\rho
$$

where $Q^{*}=-Q /\left(a_{P}+a_{P C} C+a_{P B} B\right)$ is the semi-elasticity of market demand.

To measure the effects of the cartel continued between 21.8.2007 and 22.9.2011 on competition in the market, we firstly create two alternative specifications. In the first specification, we use a dummy variable named $D$ taking the value 1 for the period between 
21.8.2007 and 22.9.2011 and taking the value of 0 in other months. Alternatively, instead of the $D$ dummy variable, we use a variable named $K$ in order to measure the total market share of the banks taking part in cartel. In sum, the conduct parameter to measure the competition intensity is defined as follows:

$$
\lambda=\lambda_{0}+\lambda_{D} D \quad \text { or } \quad \lambda=\lambda_{0}+\lambda_{K} K
$$

Thus, according to the first specification, $\lambda_{0}$ is the degree of competition when the cartel does not exist while $\lambda=\lambda_{0}+\lambda_{D}$ measures the competition during the cartel period. As can be seen from the Table 1, the value of the variable $\mathrm{K}$ may vary and takes its highest level as 0.88 , meaning that the largest total market share of the cartel members was $88 \%$. Thus, according to the second specification, $\lambda_{0}$ is the degree of competition when the cartel does not exist while $\lambda=\lambda_{0}+\lambda_{K} K$ (but not $\lambda=\lambda_{0}+\lambda_{K}$ ) measures the competition during the cartel period.

We use the nationwide monthly aggregates for Turkish banks over period January 2005 and October 2017. Consumer loans offered by banks $(Q)$ is deflated using the Consumer Price Index (CPI). Personnel expenses $(E)$ is also deflated using the CPI and Total Assets in the sector. Deflated personnel expenses in this way are abbreviated by $E 1$ and E2 and are used in different model specifications. Table 1 describes summary statistics of the 154 observations for each variable, while four different models studied are presented in Table 2.

Table: 1

Descriptive Statistics of Variables $(n=154)$

\begin{tabular}{|c|c|c|c|c|c|}
\hline Variable & Description & Mean & Std. Dev. & Min & Max \\
\hline$Q$ & Consumer Loans Offered by Banks Deflated by CPI & 716.01 & 316.28 & 110.85 & 1171.21 \\
\hline$P$ & Weighted Average Interest Rates on Consumer Loans Offered by Banks & 16.63 & 3.75 & 10.00 & 26.38 \\
\hline$C$ & Consumer Confidence Index & 81.45 & 11.54 & 58.52 & 105.43 \\
\hline$B$ & Average Cost of Domestic Borrowing & 12.15 & 4.08 & 6.25 & 20.27 \\
\hline$R$ & Weighted Average Interest Rates Applied to Bank Deposits & 11.73 & 3.91 & 5.95 & 19.32 \\
\hline E1 & Personnel Expenses Deflated by CPI & 5.1 & 0.8 & 3.2 & 6.4 \\
\hline E2 & Personnel Expenses Deflated Total Assets & $9.9 \mathrm{e}-4$ & $2.1 \mathrm{e}-4$ & $6.6 \mathrm{e}-4$ & $1.5 \mathrm{e}-3$ \\
\hline$D$ & Dummy Variable for Cartel & 0.32 & 0.47 & 0 & 1 \\
\hline$K$ & Total Market Share of the Cartel Member Banks & 0.24 & 0.37 & 0 & 0.88 \\
\hline
\end{tabular}
Notes: Data were acquired from Banks Association of Turkey (BAT) and Turkish Statistical Institute (TUIK) web site. Summary statistics were calculated by the author.

Table: 2

Alternative Model Specifications

\begin{tabular}{|c|c|c|c|c|c|}
\hline Variable & Description & Model-1 & Model-2 & Model-3 & Model-4 \\
\hline$Q$ & Consumer Loans Offered by Banks Deflated by CPI & $\sqrt{ }$ & $\sqrt{ }$ & $\sqrt{ }$ & $\sqrt{ }$ \\
\hline$P$ & Weighted Average Interest Rates on Consumer Loans Offered by Banks & $\sqrt{ }$ & $\sqrt{ }$ & $\sqrt{ }$ & $\sqrt{ }$ \\
\hline$C$ & Consumer Confidence Index & $\sqrt{ }$ & $\sqrt{ }$ & $\sqrt{ }$ & $\sqrt{ }$ \\
\hline$B$ & Average Cost of Domestic Borrowing & $\sqrt{ }$ & $\sqrt{ }$ & $\sqrt{ }$ & $\sqrt{ }$ \\
\hline$R$ & Weighted Average Interest Rates Applied to Bank Deposits & $\sqrt{ }$ & $\sqrt{ }$ & $\sqrt{ }$ & $\sqrt{ }$ \\
\hline E1 & Personnel Expenses Deflated by CPI & $\sqrt{ }$ & $\times$ & $\sqrt{ }$ & $\times$ \\
\hline E2 & Personnel Expenses Deflated Total Assets & $\times$ & $\sqrt{ }$ & $\times$ & $\sqrt{ }$ \\
\hline$D$ & Dummy Variable for Cartel & $\sqrt{ }$ & $\sqrt{ }$ & $\times$ & $x$ \\
\hline$K$ & Total Market Share of the Cartel Member Banks & $x$ & $\times$ & $\sqrt{ }$ & $\sqrt{ }$ \\
\hline
\end{tabular}


Equations (7) and (8) consist of a system of equations to be estimated; and in such a system, the simultaneity problem may be observed when some of the endogenous variables are located at the right-hand side of the equations. Turning to our model, the endogenous variable $P$ appears as the explanatory variable in the demand function (7), while other endogenous variable, $Q$, enters as the explanatory variable into the supply relation (8). The application of a single equation (limited information) method such as ordinary least squares (OLS) to this model yields biased and inconsistent estimates. Thus, the demand function (7) and supply relation (8) should be estimated via a system estimator such as three-stage least squares (3SLS) or full information maximum likelihood (FIML). We employed 3SLS by using the following instruments: Weighted average interest rates applied to bank deposits $(R)$, personnel expenses (E1 or E2), dummy variable for cartel $(D)$, lag of the weighted average interest rates on consumer loans offered by banks $\left(P_{-1}\right)$ and lag of consumer loans offered by bank $\left(Q_{-1}\right)$ are the instruments for the demand equation (7). As for the supply relation (8), consumer confidence index $(C)$, average cost of domestic borrowing $(B)$, lag of the weighted average interest rates on consumer loans offered by banks $\left(P_{-1}\right)$ and lag of consumer loans offered by bank $\left(Q_{-1}\right)$ are selected as instruments.

\section{Estimation Results}

The estimation results for the demand equation (7) and the supply relation (8) are reported in Table 3. Although some of the coefficients are statistically significant, they cannot be interpreted directly due to the interaction terms ${ }^{8}$. However, among the parameters estimated, the $\lambda_{\mathrm{s}}\left(\lambda_{0}, \lambda_{D}\right.$ and $\left.\lambda_{K}\right)$ are important in measuring the effects of the cartel on the competition in the market, and we can directly interpret their values. The results are found to be very robust against alternative specifications: As stated above, in all four models, $\lambda_{0}$ provides information on the intensity of the competition in the market when the cartel does not exist. The value of the parameter is varying between 0.01 and 0.02 in four alternative models, and none of them is statistically different from zero. It suggests that we cannot reject the hypothesis that the Turkish consumer loan market was perfectly competitive, and all banks acted as price (loan interest rate) takers during the non-cartel period.

8 Several studies prefer to calculate the price elasticities at the mean values of the variables (see, Buschena \& Perloff, 1991; Çelen \& Günalp, 2010; Nakane, 2001; Coccorese \& Pellecchia, 2013). However, actually we do not have any theoretical reasoning for using mean values in the calculation of the elasticities, because these mean values are not indeed observed during any period studied. 


\section{Table: 3}

Estimation Results of Alternative Model Specifications

\begin{tabular}{|c|c|c|c|c|}
\hline Parametre & Model-1 & Model-2 & Model-3 & Model-4 \\
\hline \multicolumn{5}{|c|}{ Demand Function (Equation-7) } \\
\hline$a_{0}$ & $\begin{array}{c}-2,789.5 \\
(-1.1)\end{array}$ & $\begin{array}{c}-905.9 \\
(-0.6)\end{array}$ & $\begin{array}{c}-3,218.9 \\
(-1.2)\end{array}$ & $\begin{array}{c}-1,200.1 \\
(-0.7)\end{array}$ \\
\hline$a_{P}$ & $\begin{array}{l}288.8 \\
(2.1)^{* * *}\end{array}$ & $\begin{array}{l}184.5 \\
(2.0)^{* * *}\end{array}$ & $\begin{array}{l}313.8 \\
(2.2) * *\end{array}$ & $\begin{array}{c}201.7 \\
(2.2)^{* * *}\end{array}$ \\
\hline$a_{C}$ & $\begin{array}{l}-19.7 \\
(-1.2)\end{array}$ & $\begin{array}{c}-24.2 \\
(-2.0)^{* *}\end{array}$ & $\begin{array}{l}-15.4 \\
(-0.9)\end{array}$ & $\begin{array}{l}-20.7 \\
(-1.7)\end{array}$ \\
\hline$a_{P C}$ & $\begin{array}{c}0.5 \\
(0.5)\end{array}$ & $\begin{array}{c}0.7 \\
(1.0)\end{array}$ & $\begin{array}{c}0.3 \\
(0.3)\end{array}$ & $\begin{array}{c}0.5 \\
(0.7)\end{array}$ \\
\hline$a_{B}$ & $\begin{array}{c}448.9 \\
(2.7)^{* * * *}\end{array}$ & $\begin{array}{c}315.0 \\
(3.0)^{* * *}\end{array}$ & $\begin{array}{c}455.4 \\
(2.7)^{* * * *}\end{array}$ & $\begin{array}{c}316.3 \\
(3.0)^{* * * * *}\end{array}$ \\
\hline$a_{P B}$ & $\begin{array}{l}-27.1 \\
(-2.9)\end{array}$ & $\begin{array}{c}-19.7 \\
(-3.4)^{* * * *}\end{array}$ & $\begin{array}{c}-27.4 \\
(-2.9)^{* * * *}\end{array}$ & $\begin{array}{c}-19.8 \\
(-3.3)^{* * * *}\end{array}$ \\
\hline \multicolumn{5}{|c|}{ Supply Relation (Equation-8) } \\
\hline$b_{0}$ & $\begin{array}{l}16.6 \\
(1.5)\end{array}$ & $\begin{array}{l}21.7 \\
(1.7)^{*}\end{array}$ & $\begin{array}{l}15.3 \\
(1.6)\end{array}$ & $\begin{array}{l}20.0 \\
(0.7)\end{array}$ \\
\hline$b_{Q}$ & $\begin{array}{c}-0.001 \\
(-0.007) \\
\end{array}$ & $\begin{array}{l}-0.006 \\
(-0.61)\end{array}$ & $\begin{array}{l}7 \mathrm{e}(-4) \\
(-0.05)\end{array}$ & $\begin{array}{l}-0.005 \\
(-0.57) \\
\end{array}$ \\
\hline$b_{R}$ & $\begin{array}{c}0.4 \\
(0.7) \\
\end{array}$ & $\begin{array}{c}0.5 \\
(0.8) \\
\end{array}$ & $\begin{array}{c}0.5 \\
(0.8) \\
\end{array}$ & $\begin{array}{c}0.6 \\
(1.0) \\
\end{array}$ \\
\hline$b_{E I}$ & $\begin{array}{c}-0.7 \\
(-0.3) \\
\end{array}$ & - & $\begin{array}{c}-0.6 \\
(-0.3) \\
\end{array}$ & - \\
\hline$b_{E 2}$ & - & $\begin{array}{c}-6,496.1 \\
(-0.7) \\
\end{array}$ & - & $\begin{array}{c}-6,131.9 \\
(-0.5)\end{array}$ \\
\hline \multicolumn{5}{|c|}{ Conduct Parameter (Equation-9) } \\
\hline$\lambda_{0}$ & $\begin{array}{c}0.02 \\
(0.08) \\
\end{array}$ & $\begin{array}{c}0.01 \\
(0.12) \\
\end{array}$ & $\begin{array}{c}0.02 \\
(0.09) \\
\end{array}$ & $\begin{array}{c}0.02 \\
(0.15) \\
\end{array}$ \\
\hline$\lambda_{D}$ & $\begin{array}{c}0.65 \\
(1.52)^{\mathrm{a}} \\
\end{array}$ & $\begin{array}{c}0.43 \\
(1.47)^{\mathrm{b}}\end{array}$ & - & - \\
\hline$\lambda_{K}$ & - & - & $\begin{array}{c}0.74 \\
(1.58)^{\mathrm{c}}\end{array}$ & $\begin{array}{c}0.48 \\
(1.53)^{\mathrm{d}}\end{array}$ \\
\hline
\end{tabular}

Notes: Figures in parentheses are t-stastistics.

* significant at 10\%, ** significant at 5\%, *** significant at 1\%.

a: $p$-value of the parameter $\lambda_{D}$ in Model-1 is 0.129 .

$b$ : p-value of the parameter $\lambda_{D}$ in Model-2 is 0.142 .

c: p-value of the parameter $\lambda_{K}$ in Model-3 is 0.115 .

$d$ : p-value of the parameter $\lambda_{K}$ in Model-4 is 0.127.

In Model-1 and Model-2, the parameter $\lambda_{D}$ measures the effects of the cartel on the consumer loan interest rates. In both models the sign of this parameter is positive $(0.65$ and 0.43 respectively), indicating that the competition in the market decreased due to the cartel. In addition, based on the respective p-values which are rather close to 10 per cent $(0.129$ and 0.142 ), we may conclude that the negative effect of the cartel on the competition intensity is statistically significant at the reasonable significance levels.

As stated above, $\lambda=\lambda_{0}+\lambda_{D}$ provides information regarding the intensity of the competition during cartel period. To investigate whether summation of these parameters equal to zero (perfect competition case) or to one (full collusion case), we carried several Wald tests presented in Table 4. The most striking finding is that, in contrast to non-cartel period, we rejected the hypothesis of perfectly competitive market case during the cartel period, according to the results of both models. Indeed, this result is not surprising given that we found above that the parameter $\lambda_{D}$ measuring the effects of the cartel on the consumer loan interest rates is positive and statistically significant. In conclusion, both models witness that the cartel formed by the banks helped them to avoid the perfectly competitive market conditions observed during non-cartel period. 
Table: 4

Wald Test Results

\begin{tabular}{|c|c|c|c|}
\hline Models & Null Hypothesis & Statistic & p-value \\
\hline \multirow{2}{*}{ Model-1 } & $\mathrm{H}_{0}: \lambda_{0}+\lambda_{D}=0$ & 3.11 & $0.078^{*}$ \\
\cline { 2 - 4 } & $\mathrm{H}_{0}: \lambda_{0}+\lambda_{D}=1$ & 0.78 & 0.376 \\
\hline \multirow{2}{*}{ Model-2 } & $\mathrm{H}_{0}: \lambda_{0}+\lambda_{D}=0$ & 3.19 & $0.074^{*}$ \\
\cline { 2 - 4 } & $\mathrm{H}_{0}: \lambda_{0}+\lambda_{D}=1$ & 5.18 & $0.023^{* *}$ \\
\hline
\end{tabular}

* the relevant null hypothesis is rejected at $10 \%$ significance level;

** the relevant null hypothesis is rejected at $5 \%$ significance level.

After determining the cartel decreased the competition in the market significantly, we test whether the market shifted from perfect competition to the full collusion thanks to the cartel. The banks achieved to operate in full collusion during the cartel period according to the Model-1 while Model-2 suggests that the hypothesis of full collusion during cartel period is rejected at 5\% significance level, but not rejected at $1 \%$ significance level. After all, one may confidently claim that the competition in the market has been distorted extensively as a result of the cartel and thus market conditions have approached to the full collusion.

In Model-3 and Model-4, the values of the parameter $\lambda_{K}$ are found 0.74 and 0.48 , and they are statistically significant at almost 10 per cent significance levels (p-values are 0.115 and 0.127 respectively). However, the interpretation of the parameter $\lambda_{K}$ is different from that of parameter $\lambda_{D}$ : In Model-1 and Model-2 we assume that the market power of the cartel member during the cartel period is stable and $\lambda=\lambda_{0}+\lambda_{D}$ measures the strength of the cartel. In contrast, in Model-3 and Model-4 the market power of the cartel is measured by $\lambda=\lambda_{0}+\lambda_{K} K$ and it varies depending on the total market shares $(K)$ of the cartel members in any given time period. Thus, $\lambda_{K}$ measures the change in the conduct parameter $(\lambda)$ if all banks take part in the cartel suddenly. To be more specific, the value 0.74 of the parameter $\lambda_{K}$ in Model-3 means that if the banks enters into the cartel suddenly, the market power parameter $(\lambda)$ will increase by 0.74 . For a more specific and realistic example, if a bank with the market share of the 10 per cent enters into the cartel, then the market power parameter $(\lambda)$ will increase and approach to the full collusion case by 0.074 .

To compare the results of four alternative models, we plot their conduct (market power) parameter estimations $\left(\lambda=\lambda_{0}+\lambda_{D} D\right.$ in the former two models; $\lambda=\lambda_{0}+\lambda_{K} K$ in the latter two models) throughout the time period studied. As can be shown by Figure-1, the upward jump in the parameter due to the cartel is obvious in all alternative models. 
Figure: 1

Conduct (Market Power) Parameter Estimations of the Alternative Models

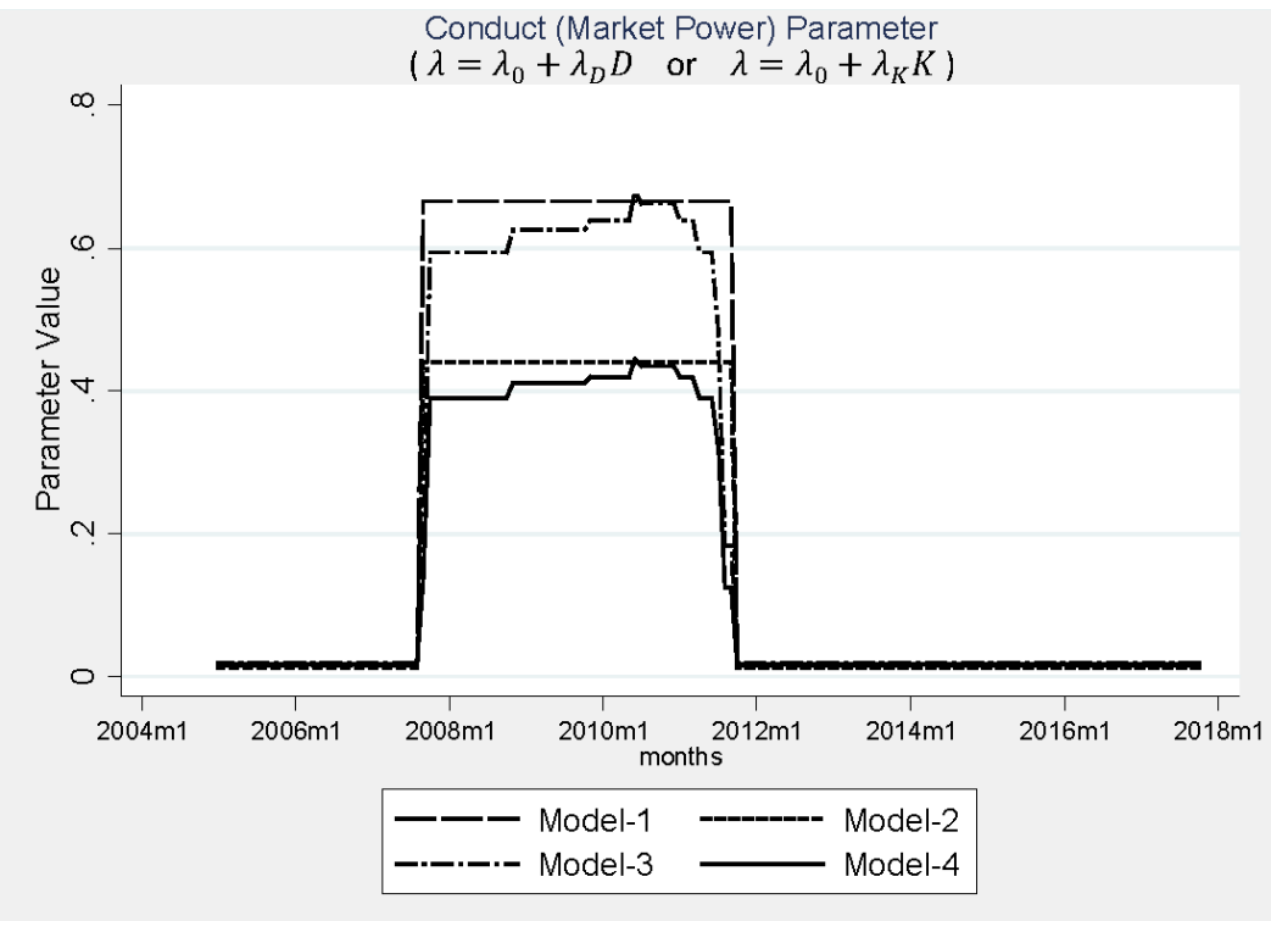

\section{Conclusion}

Turkish Competition Act has been enforced since 1997 by the Competition Board, which is an independent regulatory agency endowed with public power to preserve the competition in all markets without any exception. Among them, the banking market has always remained under scrutiny of the Competition Board. Following three separate investigations, the Board reached the conclusion of the competition infringement, and thus levied administrative fines on Turkish banks and global banks operating in Turkey.

Among three decisions imposing fines on banks, the second one taken in March 2013 has the utmost importance. Carrying out an extensive investigation on major 12 Turkish banks, the Board concluded that the banks colluded in the period 2007-2011 by fixing interest rates for deposit, loan and credit card services. The total amount of the fine applied in this decision is the highest fine throughout the Board's history. In addition, with this decision, the Board levied its highest fine ever imposed on a single undertaking.

The main motivation of our study is to measure the anticompetitive effects of the infringements found by the Competition Board in its above-mentioned decision. To be more 
specific, we focused on the consumer loan submarket, and aimed to estimate the likely impact of the cartel on the intensity of the competition in this submarket. For this aim, we utilized proverbial Bresnahan-Lau model, the most popular model working in the conjectural variation framework.

We studied the consumer loan market for the time period between January 2005 and October 2017, and divided this period into two sections, cartel and non-cartel period, according to the relevant decision of the Competition Board. Cartel period includes the months between September 2007 and September 2011 while the other months are part of the non-cartel period. We created four different alternative models and all of them provide rather consistent and robust results. Accordingly, the banks operated in perfectly competitive conditions when they did not form a cartel. That is to say that during the non-cartel period they did not have a considerable amount of market power. However, with the beginning of the cartel enforcement in September 1997, the consumer loan market shifted significantly to a more collusive and less competitive environment and approached to the monopolistic market conditions. The destructive effect of the cartel on the competition is very obvious, and this result is robust across all alternative model specifications. In addition, this finding is fully in line with that of the Aydemir (2013), which studied the loan market in a similar framework.

The key contributions of this study to the literature are practical ones: We derived two obvious lessons and suggestions for Competition Board and Turkish banks separately. Firstly, this study witnessed that the Competition Board was right to impose fines on banks after its recent investigation. In other words, our finding justifies the heavy fines imposed by the Board. Thus, one policy implication derived from our study is that the Board should keep enforcing the Competition Act intrepidly in all markets without exception. Secondly, as for the banks, they should take the Competition Act more seriously and follow the competition compliance programs heartedly to escape from more serious sanctions in the coming years.

Two limitations of our study may be mentioned. First, we specifically focused on consumer loan submarket although the relevant Board decision includes not only all sections of the loan market but also deposit market. Thus, this study may be extended to measure the likely impact of the cartel on the competition in other ignored markets. Second, we neglected dynamic nature of the banking industry by assuming that all variables used are stationary. Steen and Salvanes (1999) re-specified the static Bresnahan-Lau model in a dynamic Error Correction Mechanism (ECM) framework. Thus, one natural extension of the paper would be to utilise Steen and Salvanes (1999) model to measure the effect of the cartel on the competition in the banking sector.

\section{References}

Aydemir, R. (2013), "Competition and Collusion in the Turkish Banking Industry", Emerging Markets Finance and Trade, 49(Suppl. 5), 31-40. 
Aydemir, R. (2014), "Empirical Analysis of Collusive Behaviour in the Turkish Deposits Market", Economic Research-Ekonomska Istraživanja, 27(1), 527-538.

Beck, T. (2008), "Bank Competition and Financial Stability: Friends or Foes?", Policy Research Working Paper 4656, World Bank, Washington, DC.

Bowley, A. (1924), The Mathematical Groundwork of Economics, Oxford University Press.

Bresnahan, T.F. (1982), “The Oligopoly Solution Concept is Identified”, Economic Letters, 10, 87 92.

Buschena, D.E. \& J.M. Perloff (1991), "The Creation of Dominant Firm Market Power in the Coconut Oil Export Market”, American Journal of Agricultural Economics, 73, 10011008 .

Carletti, E. \& P. Hartmann (2002), "Competition and Stability in Banking: What's Special about Banking", ECB Working Paper No. 146.

Coccorese, P. \& A. Pellecchia (2013), "Multimarket Contact, Competition and Pricing in Banking", Journal of International Money and Finance, 37, 187-214.

Çelen, A. \& B. Gunalp (2010), "Do Investigations of Competition Authorities Really Increase the Degree of Competition? An Answer from Turkish Cement Market", Prague Economic Papers, 19(2), 150-168.

Demirel, O. \& S.A. Hatırl1 (2017), "Measuring the Market Power of the Banking Sector in Turkey", Akademik Araştırmalar ve Çalışmalar Dergisi, 9(16), 20-34.

Gonlusen, Y. (2013), "The Turkish Competition Board Imposes Fines on 12 Banks for Collusion in the Cash Deposit, Credit and Credit Card Services Markets", E-Competitions Bulletin, Art. No: 51291.

Jung, C. \& B.J. Seldon (1995), “The Degree of Competition in the Advertising Industry”, Review of Industrial Organization, 10, 41-52.

Korkmaz, A. (2010), “Türk Mevduat Bankacıllğı Sektöründe Rekabet Derecesi Bresnahan-Lau Modeli'nden Kanitlar”, Bankactlar Dergisi, 74, 3-19.

Lau, L.J. (1982), "On Identifying the Degree of Competitiveness from Industry Price and Output Data”, Economics Letters, 10, 93-99.

Leon, F. (2014), "Measuring Competition in Banking: A Critical Review of Methods", Working Papers 201412, CERDI.

Mensi, S. (2010), "Measurement of Competitiveness Degree in Tunisian Deposit Banks: An application of the Panzar and Rosse model", Panoeconomicus, 57(2), 189-207.

Nakane, M.I. (2001), “A Test of Competition in Brazilian Banking”, Central Bank of Brazil, Office of Sao Paulo, Research Department, Working Paper, No. 12.

Qin, B. \& S. Shaffer (2014), “A Test of Competition in Chinese Banking”, Applied Economics Letters, 21(9), 602-604.

Reuters (2013), Turkish Banks Deny Cartel Involvement in Rate-Setting Probe, $<$ https://www.reuters.com/article/turkey-banks-probe/turkish-banks-deny-cartelinvolvement-in-rate-setting-probe-idUSL6N0BP5BS20130225>, 19.03.2019.

Sahin, E. (2017), “The Cartel of 12 Turkish Banks and Consumer Harm: What Happens Now?”, European Competition Law Review, 38(4), 180-186.

Shaffer, S. (1989), “Competition in the US Banking Industry”, Economics Letters, 29, 321-323. 
Shaffer, S. (1993), "A Test of Competition in Canadian Banking”, Journal of Money, Credit, and Banking, 25(1), 49-60.

Suominen, M. (1994), "Measuring Competition in Banking: A Two Product Model”, Scandinavian Journal of Economics, 96(1), 95-110.

Swank, J. (1995), "Oligopoly in Loan and Deposit Markets: An Econometric Application to the Netherlands", De Economist, 143, 353-366.

Steen, F. \& G.K. Salvanes (1999), "Testing for Market Power Using a Dynamic Oligopoly Model”, International Journal of Industrial Organisation, 17, 147-177.

TBB (2012), “Türkiye’de Bankacılık Sektörü Piyasa Yapısı, Firma Davranışları ve Rekabet Analizi”, Türkiye Bankalar Birliği, Yayın No. 280.

Toolsema, L.A. (2002), "Competition in the Dutch Consumer Credit Market”, Journal of Banking and Finance, 26, 2215-2229.

UNCTAD (2016), “Competition Guidelines: Leniency Programme”, United Nations Publication, UNCTAD/DITC/CLP/2016/3.

Várhegyi, É. (2004), “Bank Competition in Hungary”, Acta Oeconomica, 54(4), 403-424.

Zardkoohi, A. \& D.R. Fraser (1998), "Geographical Deregulation and Competition in US Banking Markets”, Financial Review, 33, 85-98. 
Çelen, A. (2019), "Anticompetitive Effects of the Banking Cartel in Turkish Loan Market”, Sosyoekonomi, Vol. 27(40), 211-227. 